\title{
Development of a hamburger-type product derived from bovine liver
}

\author{
Cibele Maria de Araújo ROCHA ${ }^{1 *}$, Erilane de Castro Lima MACHADO², Eduardo Henrique Leite MACHADO², \\ Silvio Assis de Oliveira FERREIRA², Samara Alvachian Cardoso ANDRADE ${ }^{3}$
}

\begin{abstract}
Changes in eating habits generated a demand for processed foods. The use of bovine liver in processed foods provides nutritional enrichment; the use of oatmeal promotes moisture and fat substitution. This study evaluated hamburger-type products derived from bovine liver. Three formulations were prepared using bovine liver and containing $0 \%, 5 \%$, and $10 \%$ oatmeal. The products were evaluated for moisture, protein, carbohydrates, lipids, and ash contents and presence of thermotolerant coliforms, coagulase positive staphylococci, Salmonella sp., Bacillus cereus, and Clostridium sulfite reducers. Yield percentage, sensory acceptance, and purchase intent were evaluated through child and adult sensory panels. The products with oatmeal presented lower lipid content and higher carbohydrate content than products without oatmeal. The microbiological analysis showed products with counts $<10 \mathrm{CFU} / \mathrm{g}$ for thermo-tolerant coliforms and coagulase positive staphylococci, and absence of Salmonella sp., Bacillus cereus, and Clostridium sulfite reducers. The child sensory panel classified the products using hedonic terms; this group demonstrated interest in consuming the products. The adult sensory panel classified the $5 \%$ oatmeal product with the best acceptability indexes. This group demonstrated satisfactory purchase intent. It is concluded that the use of bovine liver as a raw material for the production of hamburger-type products is feasible.
\end{abstract}

Keywords: hamburger-type product; sensory analysis; fat substitutes.

Practical Application: Bovine liver can be used as raw material for the production of hamburger-type products.

\section{Introduction}

The eating habits of populations have undergone changes that are significantly motivated by the processes of urbanization, industrialization, the professionalization of women, and reduction of time for food preparation and/or consumption. This context favors the consumption of industrialized products or products prepared outside of homes (Lima \& Oliveira, 2005; Fattori et al., 2005; Marques, 2007).

The hamburger, a particular favorite among children and adolescents and very popular among adults, has become a growing option (Levrè et al., 2000; Tavares \& Serafini, 2008) as a quick, cheap, and ready-to-eat meal and is commonly offered in fast food restaurant chains.

Hamburgers have become a popular food because of its convenience of preparation, nourishing attributes, and ability to satisfy hunger, aspects which fit the lifestyle of people living in large urban centers (Arisseto, 2003). There is also a new trend in the relationship between consumers and food, where the population selects food based on its nutritional value as well as its proper preparation to avoid illnesses (Lacerda \& Cunha, 2001).

Alternatives have been used to improve acceptance and nutritional value of hamburgers, either by substitution or association between different raw materials (Fernandes et al.,
2013) and the addition of new ingredients, in particular fat substitutes, such as oatmeal (Salvino et al., 2009).

Slaughterhouse by-products such as blood, liver, heart, kidneys, and brain present excellent nutritional value (Hsieh \& Ofori, 2011). The bovine liver is rich in vitamins, iron, and phosphorus compared to red meat (Universidade Estadual de Campinas, 2011; Kim, 2011), and is rich in a wide variety of mineral salts and trace elements (García-Llatas et al., 2011). In addition, bovine liver presents an average nutritional composition of $21 \%$ protein and 5\% lipids; therefore, it is a raw material option that can increase the nutritional value of new food products.

Thus, the objective of this study was to elaborate hamburger-type products based on the evaluation of physical-chemical characteristics, yield, microbiological quality, sensorial acceptance, and purchase intent.

\section{Materials and methods}

The study was carried out in the Dietary Technique, Bromatology, and Food Microbiology laboratories of the Federal University of Pernambuco, at the Academic Center of Vitória de Santo Antão campus (UFPE-CAV). 
Bovine liver and other ingredients were purchased at a commercial establishment in the city of Vitória de Santo Antão, PE. The bovine liver was purchased frozen and transported in an isothermal container to the laboratory of Dietary Technique where it remained frozen $\left(-18^{\circ} \mathrm{C}\right)$ until use. The hamburger-type products were prepared according to the formulations presented in Table 1.

Three products were prepared with different percentages of the bovine liver $(80 \%, 75 \%$, and $70 \%)$ and oatmeal $(0 \%, 5 \%$, and $10 \%)$; the percentages of other ingredients were the same in all formulations (Table 1).

The bovine liver was thawed at refrigeration temperature $\left(5^{\circ} \mathrm{C}\right)$ for 10 hours, the connective tissue was removed, and the liver was diced to facilitate grinding. Diced liver and ingredients were shredded together in a food processor for about 2 minutes until a homogenous mass was formed. This mass was shaped into hamburger patties with the aid of a Petri dish, and the final product $(100 \mathrm{~g})$ was wrapped in plastic film (polyvinyl chloride) and packed in polyethylene bags. The hamburgers were stored frozen $\left(-18^{\circ} \mathrm{C}\right)$ for a period of not more than 10 days until all analyses were performed.

The physicochemical analysis was carried out in triplicate and the following contents were evaluated: moisture (through the gravimetric method in an oven at $105^{\circ} \mathrm{C}$ ), protein (Kjeldahl method), total fat (Soxhlet method), ashes (gravimetric method in a muffle at $450^{\circ} \mathrm{C}$ ), and carbohydrate (by the difference between fractions) and according to the Instituto Adolfo Lutz (2005).

Thermotolerant coliforms, coagulase positive staphylococci, Salmonella sp, Bacillus cereus, and Clostridium sulfite were determined in the finished products according to Resolution RDC $\mathrm{n}^{\circ} 12$ (Brasil, 2001) for chilled or frozen raw meat products.

The products' percentage yield was calculated by the difference in weight between raw and cooked samples (Berry, 1992).

This study was submitted to the Ethics Committee of the Federal University of Pernambuco (UFPE) and approved under the Ethical Assessment Certificate (CAAE) number 0404.0.172.000-10. All participants agreed to participate and signed an informed consent form before the study start.
The sensory testing was performed in two panels, one composed of children and one of adults. The child panel consisted of 25 children between 7 and 8 years old, who were students of the municipal school of the city of Vitória de Santo Antão - Pernambuco (PE). They evaluated the products through the Hedonic Facial Scale (Brasil, 2009).

The evaluation of purchase intent by the child panel was based on four categories: "I want my parents to buy the product for consumption at home", "I wish the product was served in the school lunch", "I do not want my parents to buy the product for consumption at home", and "I would not want to have the product at the school lunch."

In the sensory analysis, samples of baked in electric plate "hamburger" type products were inserted between two slices of traditional white bread and served randomly and individually one hour and thirty minutes after the school lunch break. When the children received the samples, they chose the facial expression displayed in the hedonic facial scale that represented their level of satisfaction with each product.

The adult sensory panel was composed of 54 people, with a mean age of $23 \pm 2$ years, who are students and staff of the UFPE-CAV. The sensory test evaluated acceptance of the attributes of color, odor, appearance, taste, texture, and overall quality using a hedonic scale of 9 points. The scale's ends were anchored in the following terms according to Anzaldúa-Morales (1994): "1 - I disliked it very much" and "9 - I liked it very much". The test of purchase intent was applied using a 5-point scale where 5 (five) represented "I would certainly buy it" and 1 (one) represented "I certainly would not buy it" (Meilgaard et al., 1987). The acceptability index (AI) was calculated in the acceptance test for each of the evaluated attributes. Formulations with AI equal to or greater than $70 \%$ were considered accepted according to Equation 1 (Teixeira et al., 1987).

$A I(\%)=Y \times 100 / Z$

where: $\mathrm{Y}=$ Average obtained score; $\mathrm{Z}=$ Maximum obtained score.

All participants received a glass $(180 \mathrm{~mL})$ of mineral water to clean the palate and remove residual taste between tasting samples.

Table 1. Formulations of hamburger-type products derived from bovine liver.

\begin{tabular}{cccc}
\hline & & Formulations & \\
\cline { 2 - 4 } Ingredients & Hamburger A & Hamburger B & Hamburger C \\
\hline Bovine liver $(\mathrm{g} / 100 \mathrm{~g})$ & 80 & 75.0 & 70.0 \\
Oatmeal $(\mathrm{g} / 100 \mathrm{~g})$ & 0 & 5.0 & 10 \\
Ice $(\mathrm{g} / 100 \mathrm{~g})$ & 10 & 10 & 10 \\
Salt $(\mathrm{g} / 100 \mathrm{~g})$ & 1.5 & 1.5 & 1.5 \\
Textured soybean protein (TSP) $(\mathrm{g} / 100 \mathrm{~g})$ & 2.0 & 2.0 & 2.0 \\
Cumin $(\mathrm{g} / 100 \mathrm{~g})$ & 1 & 1.0 & 1.0 \\
Garlic $(\mathrm{g} / 100 \mathrm{~g})$ & 2.0 & 2.0 & 2.0 \\
Onion $(\mathrm{g} / 100 \mathrm{~g})$ & 3.5 & 3.5 & 3.5 \\
TOTAL & $100 \%$ & $100 \%$ & $100 \%$ \\
\hline
\end{tabular}

Hamburger $\mathrm{A}$ = bovine liver hamburger without oatmeal; Hamburger B = bovine liver hamburger with 5\% oatmeal; Hamburger $\mathrm{C}=$ bovine liver hamburger with $10 \%$ oatmeal 
The sensory data were analyzed by analysis of variance (ANOVA) and the Duncan test was performed to compare the means obtained at a $5 \%$ level of significance. The software "Statistics for Windows" was used in these analyses (Statsoft, 2002).

\section{Results and discussion}

\subsection{Physicochemical analysis}

The results of the centesimal analysis of the hamburger-type product derived from the bovine liver are shown in Table 2. The products differed significantly $(\mathrm{p}<0.05)$ in most parameters, except for ash content and protein content when comparing formulations containing oatmeal. The products without oatmeal were characterized with higher protein, lipid, and moisture contents and lower carbohydrate content compared to those prepared with oatmeal.

Results (Table 2) suggest that protein values were influenced by the addition of oatmeal. It is believed that the lower protein content in the products with oatmeal (Hamburger B and C) resulted from a reduction in the amount of bovine liver added to the formulation as a consequence of the addition of oatmeal. This may have also influenced the moisture level results because bovine liver presents higher moisture content than oatmeal (Universidade Estadual de Campinas, 2011). The mean values of protein content in the developed formulations were lower than those reported in ostrich meat hamburger with $19.74 \%$ (Hautrive et al., 2008) and alligator hamburger with 19.10\% (Fernandes et al., 2013). However, there was no incorporation of fat substitutes in the formulation of the ostrich and alligator hamburgers. Nevertheless, the products developed in this study showed protein content higher than that found in capybara hamburger with $14.4 \%$ (Pinto et al., 2007), and cashew nut hamburger with added vegetable protein, containing a total of $5.75 \%$ protein (Ribeiro, 2008).

In this study, the gradual addition of oatmeal resulted in an increase in total amount of carbohydrates and reduction in total lipid concentration; however, these products presented higher carbohydrates content when compared to rabbit hamburger, with 8.8\% (Tavares et al., 2007), and contained four times the amount of carbohydrates found in cashew nut hamburger (Ribeiro, 2008).

According to Colmenero (2000), conventional meat products typical of fast-food products have high-fat contents that range from 20 to $30 \%$. The formulations proposed in this study aimed to meet the consumers' demand for food that is rich in protein with low lipid content. Queiroz et al. (2005) commented that the replacement of animal fat by the use of mimetics (carbohydrates, gums, and proteins) could provide an improvement in the sensory characteristics of these products.

Santos-Júnior et al. (2009) also used oatmeal in their preparation of sheep meat hamburger formulations and obtained favorable results regarding the reduction of fat content; these authors observed higher sensory acceptance for the formulation containing $4 \%$ oatmeal than the product without oatmeal. Similar results were found by Ferreira et al. (2012).

\subsection{Microbiological analysis}

The microbiological analyses showed that the processed products had a count $<10 \mathrm{CFU} / \mathrm{g}$ (Colony Forming Units per g) of thermo-tolerant coliforms and coagulase positive staphylococci, and absence of Salmonella sp., Bacillus cereus, and Clostridium sulfite reducers, indicating that the preparation followed the hygienic-sanitary standard and revealing that the products were suitable for human consumption.

\subsection{Product yield}

Hamburger A presented the lowest yield (76.45\%) when compared to the formulations supplemented with $5 \%$ and $10 \%$ of oatmeal, which presented yields of $82.82 \%$ and $86.72 \%$, respectively (Table 3 ).

Thus, increasing concentrations of oatmeal in the formulations resulted in increasing yield percentages. According to Marques (2007), proportionally increased yields were found in products with the addition of $6.8 \%$ and $12 \%$ oatmeal. Seabra et al. (2002) obtained similar results for sheep meat hamburgers, noting that the higher the proportion of oatmeal, the higher the yield of the product. Almeida (2011) also concluded that the addition of $4.0 \%$ oatmeal, favored lower weight loss by cooking (18.4\%) in relation to the control group. These results are similar to those reported by Pinheiro et al. (2008).

\subsection{Sensory analysis}

Child panel

Sensory analysis results obtained from the child panel did not show a significant statistical difference $(p>0.05)$ between products, which were classified using the hedonic terms between "I liked it very much" and "I liked it" indicating satisfactory

Table 2. The centesimal composition of hamburger-type products derived from bovine liver.

\begin{tabular}{ccrr}
\hline Components & Hamburger A & Hamburger B & Hamburger C \\
\hline Proteins $(\mathrm{g} / 100 \mathrm{~g})$ & $16.9 \pm 0.2 \mathrm{a}$ & $16 \pm 0.14 \mathrm{~b}$ & $16.3 \pm 0.12 \mathrm{~b}$ \\
Carbohydrates $(\mathrm{g} / 100 \mathrm{~g})$ & $9.22 \pm 0 \mathrm{c}$ & $12.16 \pm 0.55 \mathrm{~b}$ & $13.34 \pm 0.02 \mathrm{a}$ \\
Lipids $(\mathrm{g} / 100 \mathrm{~g})$ & $3.32 \pm 0.01 \mathrm{a}$ & $2.25 \pm 0.30 \mathrm{~b}$ & $1.80 \pm 0.28 \mathrm{c}$ \\
Moisture $(\mathrm{g} / 100 \mathrm{~g})$ & $68 \pm 0.24 \mathrm{a}$ & $67 \pm 0.13 \mathrm{~b}$ & $66 \pm 0.17 \mathrm{c}$ \\
Ashes $(\mathrm{g} / 100 \mathrm{~g})$ & $2.55 \pm 0.04 \mathrm{a}$ & $2.59 \pm 0.07 \mathrm{a}$ & $2.56 \pm 0.02 \mathrm{a}$ \\
\hline
\end{tabular}

Averages in the rows followed by same letters do not differ significantly at the $5 \%$ level of significance by the Duncan test. Hamburger A: bovine liver hamburger without oatmeal. Hamburger B: bovine liver hamburger with 5\% oatmeal; Hamburger C: bovine liver hamburger with $10 \%$ oatmeal.

Table 3. Yield percentages of hamburger-type products derived from bovine liver.

\begin{tabular}{cc}
\hline Products & Yield percentage (\%) \\
\hline Hamburger A & $76.45 \%$ \\
Hamburger B & $82.82 \%$ \\
Hamburger C & $86.72 \%$ \\
\hline
\end{tabular}

Hamburger $\mathrm{A}$ = bovine liver hamburger without oatmeal; Hamburger $\mathrm{B}=$ bovine liver hamburger with $5 \%$ oatmeal; Hamburger $\mathrm{C}=$ bovine liver hamburger with $10 \%$ oatmeal. 
acceptability by this panel. Oatmeal supplementation did not influence the results. Because the formulation without oatmeal was also well appreciated by the participants, and it is common for many children to be disgusted with bovine liver, these results demonstrate the feasibility of producing a hamburger-type product derived from bovine liver.

The results of the purchase intent evaluation for the three formulations was quite satisfactory because all participants responded that they wanted their parents to buy the product for consumption at home, and that they would like to have these products offered in the school lunch.

\section{Adult panel}

The results of the sensory acceptance analysis through the nine-point hedonic scale for the adult sensory panel are shown in Table 4.

According to Anzaldúa-Morales (1994), scores between 6 and 9 ("I liked it slightly" and "I liked it a lot"), obtained in the acceptance test of attributes, suggest that the product will be accepted in the consumer market from a sensory point of view. In this study, all scores were above 6 , with the exception of the appearance and color attribute for Hamburger C.

A statistically significant difference $(\mathrm{p}>0.05)$ was observed when products $\mathrm{A}$ and $\mathrm{B}$ were compared to $\mathrm{C}$ in relation to the attributes of appearance and overall quality. The presence of oatmeal influenced the perception of these attributes when added at $10 \%$ in the formulation, reducing the score obtained. According to Fernandes et al. (2013), the sensory variables were also significant for flavor, texture, and general acceptance in alligator meat hamburger. Albuquerque et al. (2009) reports that soy-based hamburger obtained great acceptance, reaching an average of 7.06 .

According to Marques (2007), the supplementation of sheep meat hamburgers with oatmeal did not present significant differences in the attributes of aroma and color, similar to the result found by Seabra et al. (2002). The liver has a strong characteristic odor; therefore, the reduction in odor perception by supplementation with oatmeal is positive for people who do not like the liver aroma. Table 5 shows the acceptance index of products, confirming acceptance.

One fundamental point when developing a new product is the evaluation of acceptability in order to predict the product's performance in the consumer market (Moscatto et al., 2004). Our results demonstrate that the products evaluated in this study are viable for commercialization. The acceptability scores (Table 4) and AI (Table 5) show that hamburger B was the best formulation with an acceptability index above $70 \%$ in all attributes. Hamburger $\mathrm{A}$ and $\mathrm{C}$ formulations show only one attribute with AI value of less than $70 \%$ odor. This score may be due to the higher amount of bovine liver in these formulations. However, the odor scores for Hamburgers A and C were close to $70 \%$ acceptability, indicating that odor was not appreciably unacceptable.

The purchase intent test of the three products was focused on the indexes of "I would certainly buy it" (60\%) and "I maybe
Table 4. Notes on the acceptance test of hamburger-type products derived from bovine liver conducted with the adult panel.

\begin{tabular}{cccc}
\hline Attributes & Hamburger A & Hamburger B & Hamburger C \\
\hline Odor & $6.89 \pm 1.66 \mathrm{a}$ & $6.43 \pm 1.58 \mathrm{a}$ & $6.09 \pm 1.57 \mathrm{a}$ \\
Flavor & $6.91 \pm 1.32 \mathrm{a}$ & $6.74 \pm 1.22 \mathrm{a}$ & $6.50 \pm 1.54 \mathrm{a}$ \\
Appearance & $6.44 \pm 1.68 \mathrm{a}$ & $6.55 \pm 1.30 \mathrm{a}$ & $5.94 \pm 1.52 \mathrm{~b}$ \\
Color & $6.50 \pm 1.65 \mathrm{a}$ & $6.37 \pm 1.40 \mathrm{a}$ & $5.96 \pm 1.39 \mathrm{a}$ \\
Texture & $7.15 \pm 1.44 \mathrm{a}$ & $7.11 \pm 1.37 \mathrm{a}$ & $6.93 \pm 1.53 \mathrm{a}$ \\
Overall quality & $6.85 \pm 1.50 \mathrm{a}$ & $6.98 \pm 1.16 \mathrm{a}$ & $6.33 \pm 1.54 \mathrm{~b}$ \\
\hline
\end{tabular}

Averages in the rows followed by same letters do not differ significantly at the $5 \%$ level of significance by the Duncan test. Hamburger $\mathrm{A}=$ bovine liver hamburger without oatmeal; Hamburger $\mathrm{B}=$ bovine liver hamburger with $5 \%$ oatmeal; Hamburger $\mathrm{C}=$ bovine liver hamburger with $10 \%$ oatmeal.

Table 5. Acceptability index of hamburger-type products derived from bovine liver.

\begin{tabular}{cccc}
\hline Attributes & Hamburger A & Hamburger B & Hamburger C \\
\hline Odor & 69.7 & 71.4 & 67.3 \\
Flavor & 76.7 & 74.8 & 72.2 \\
Appearance & 71.5 & 72.7 & 74.25 \\
Color & 72.2 & 70.7 & 74.5 \\
Texture & 79.4 & 79 & 77 \\
Global Quality & 76.1 & 77.5 & 70.3 \\
\hline
\end{tabular}

Hamburger A = bovine liver hamburger without oatmeal; Hamburger B = bovine liver hamburger with $5 \%$ oatmeal; Hamburger $\mathrm{C}=$ bovine liver hamburger with $10 \%$ oatmeal.

would buy it" (28\%). Hamburger A and B formulations presented the highest indexes of "I would certainly buy it" while the $\mathrm{C}$ formulation showed the highest index of "I maybe would buy it". These data confirm the AI, where all three products had satisfactory results. Albuquerque et al. (2009) and Queiroga et al. (2014) report that soy-based hamburgers and fish hamburgers, respectively, also obtained satisfactory purchase intent of $65 \%$.

\section{Conclusion}

The bovine liver can be used as raw material in the elaboration of new convenience products such as hamburger-type products. The evaluated products supplemented with oatmeal presented lower lipid content and higher percentage yield compared to those prepared without oatmeal. The elaborated products in this study were well accepted and showed satisfactory purchase intent by untrained sensory panels of children and adults.

\section{References}

Albuquerque, T. L., Lima, M. A., Oliveira, V. S., Coelho, R. M. D., \& Rodrigues, M. C. P. (2009). Processamento e aceitação sensorial de produto do tipo hambúrger à base de soja (Glycine max) e atum (Thunnus spp). Boletim do Centro de Pesquisa e Processamento de Alimentos, 27(2), 191-198. http://dx.doi.org/10.5380/cep.v27i2.22028.

Almeida, R. (2011). Processamento de hambúrguer de carne caprina adicionados com diferentes níveis de farinha de aveia (Dissertação de mestrado). Universidade Estadual do Sudoeste da Bahia, Itapetinga.

Anzaldúa-Morales, A. (1994). La evaluación sensorial de los alimentos en la teoría y la práctica. España: Acribia. 
Arisseto, A. (2003). Avaliação da qualidade global do hamburguer tipo calabresa com reduzidos teores de netrito (Dissertação de mestrado). Universidade Estadual de Campinas, Campinas.

Berry, B. W. (1992). Low fat level effects on sensory, shear, cooking, and chemical properties of ground beef patties. Journal of Food Science, 57(3), 537. http://dx.doi.org/10.1111/j.1365-2621.1992.tb08037.x.

Brasil. (2001, January 10). Regulamento técnico sobre os padrões microbiológicos para alimentos (Resolução RDC no 12, de 2 de janeiro de 2001). Diário Oficial [da] República Federativa do Brasil.

Brasil. (2009, July 17). Estabelece as normas para a execução do Programa Nacional de Alimentação Escolar (Resolução/FNDE/CD n 38, de 16 de julho de 2009). Diário Oficial [da] República Federativa do Brasil.

Colmenero, J. F. (2000). Relevant factors in strategies for fat reduction in meat products. Trends in Food Science \& Technology, 11(2), 56-66. http://dx.doi.org/10.1016/S0924-2244(00)00042-X.

Fattori, F., Souza, L., Braoios, A., \& Ramos, A. (2005). Aspectos sanitários em trailers de lanche no município de Presidente Prudente, SP. Higiene Alimentar, (19), 54-62.

Fernandes, V. R. T., Franco, M. L. R. S., Gasparino, E., Tanamati, A., Coutinho, M. E., \& Bielawski, K. (2013). Hambúrgueres de aparas de jacaré-do-pantanal (Caiman yacare) submetidos a diferentes técnicas de defumação. Arquivo Brasileiro de Medicina Veterinária e Zootecnia, 65(3), 927-933. http://dx.doi.org/10.1590/S010209352013000300043.

Ferreira, M., Mársico, E., Medeiros, R., \& Pombo, C. (2012). Comparação das características físico-químicas e sensoriais de hambúrgueres de carne bovina elaborados com cloreto de sódio, polifosfato e transglutaminase. Revista Brasileira de Medicina Veterinária, 34(1), 52-60.

García-Llatas, G., Alegría, A., \& Barberá, R. (2011). 11 minerals and trace elements. In L. Nollet \& F. Toldrá (Eds.), Handbook of analysis of edible animal by-products (pp. 183-203). Boca Raton: CRC Press. http://dx.doi.org/10.1201/b10785-15.

Hautrive, T. P., Oliveira, V. R., Silva, A. R. D., Terra, N. N., \& Campagnol, P. C. B. (2008). Análise físico-química e sensorial de hambúrguer elaborado com carne de avestruz. Food Science and Technology, 28(15), 95-101. http://dx.doi.org/10.1590/S0101-20612008000500016.

Hsieh, Y., \& Ofori, J. (2011). Food-grade proteins from animal byproducts: their usage and detection methods. In L. Nollet \& F. Toldrá (Eds.), Handbook of analysis of edible animal by-products (pp. 1335). Boca Raton: CRC Press. http://dx.doi.org/10.1201/b10785-4.

Instituto Adolfo Lutz - IAL. (2005). Normas analíticas do Instituto Adolfo Lutz: métodos físico-químicos para análise de alimentos. São Paulo: IAL.

Kim, Y. N. (2011). Vitamins, In Handbook of analysis of edible animal by-products. In L. Nollet \& F. Toldrá (Eds.), Handbook of analysis of edible animal by-products (pp. 161-182). Boca Raton: CRC Press. http://dx.doi.org/10.1201/b10785-14.

Lacerda, E., \& Cunha, A. J. (2001). Anemia ferropriva e alimentação no segundo ano de vida no Rio de Janeiro, Brasil. Revista Panamericana de Salud Pública, 9(5), 294-301. http://dx.doi.org/10.1590/S102049892001000500002 . PMid:11476017.

Levrè, E., Valentini, P., \& Chiaverini, F. (2000). Presenza di E. coli O157 verocitotossigeni in hamburger di carne bovina. Annali di Igiene: Medicina Preventiva e di Comunità, 12(2), 131-137. PMid:10863788.

Lima, J., \& Oliveira, L. (2005). O crescimento do restaurante self-service: aspectos positivos e negativos. Higiene Alimentar, (19), 45-53.
Marques, J. (2007). Elaboração de um produto de carne bovina "Tipo Hambúrguer" adicionado de farinha de aveia (Dissertação de mestrado). Universidade Federal do Paraná, Curitiba.

Meilgaard, M., Carr, B., \& Civille, G. (1987). Sensory evaluation techniques. London: CRC Press.

Moscatto, J., Prudêncio-Ferreira, S., \& Hauly, M. C. O. (2004). Farinha de yacon e inulina como ingredientes na formulação de bolo de chocolate. Food Science and Technology, 24(4), 634-640. http:// dx.doi.org/10.1590/S0101-20612004000400026.

Pinheiro, R. S. B., Jorge, A. M., Francisco, C. L., \& Andrade, E. N. (2008). Composição química e rendimento da carne ovina in natura e assada. Food Science and Technology, 28, 154-157. http://dx.doi. org/10.1590/S0101-20612008000500024.

Pinto, M. F., Ponsano, E. H. G., Almeida, A. P. S., Heinemann, R. J. B., \& Souza, W. M. (2007). Características e potencial tecnológico da carne da capivara. Ciência Rural, 37(3), 868-873. http://dx.doi. org/10.1590/S0103-84782007000300041.

Queiroga, A., Gomes, Q., \& Pereira, B. (2014). Elaboração de hambúrguer formulado com filé de peixe tucunaré (cichla ssp.). Revista Verde, 9(3), 75-80.

Queiroz, Y., Daud, K., \& Soares, R. (2005). Desenvolvimento e avaliação das propriedades físico-químicas de hambúrgueres com reduzidos teores de gordura e de colesterol. Revista Nacional da Carne, 338(2), 84-89.

Ribeiro, J. (2008). Físico-química e sensorial de hambúrguer vegetal elaborado a base de caju. Ciência e Agrotecnologia, 32(1), 191-195. http://dx.doi.org/10.1590/S1413-70542008000100028.

Salvino, É. M., Silva, J. A., Nobrega, E. S., Nascimento, J. C., Costa, M. J. C., \& Maciel, J. F. (2009). Caracterização icrobiológica, físicoquímica e sensorial de hambúrgueres de carne de avestruz (Struthio camellus), elaborados com substituto de gordura. Revista do Instituto Adolfo Lutz, 68(1), 34-41.

Santos-Júnior, L. C., Rizzatti, R., Brugnera, A., Schiavini, T. J., Campos, E. F. M., Scalco-Neto, J. F., Rodrigues, L. B., Dickel, E. L., \& Santos, L. R. (2009). Desenvolvimento de hambúrguer de carne de ovinos de descarte enriquecido com farinha de aveia. Ciência Animal Brasileira, 10(4), 1128-1134.

Seabra, L., Zapata, J., Nogueira, C., Dantas, M. A., \& Almeida, R. B. (2002). Fécula de mandioca e farinha de aveia como substitutos de gordura na formulação de hambúrguer de carne ovina. Ciência e Tecnologia, 22(3), 245-248. http://dx.doi.org/10.1590/S010120612002000300008.

Statsoft. (2002). SAS/STAT user's guide. Version 8. Tulsa: Statsoft.

Tavares, R., Cruz, A., Oliveira, T., Braga, A., Reis, F. A., Hora, I. M. C., Teixeira, R. C., \& Ferreira, E. F. (2007). Processamento e aceitação sensorial do hambúrguer de coelho (Orytolagus cunicullus). Food Science and Technology, 27(3), 633-636. http://dx.doi.org/10.1590/ S0101-20612007000300031.

Tavares, T. M., \& Serafini, Á. (2008). Avaliação microbiológica de hambúrgueres de carne bovina comercializados em sanduicherias tipo trailers em Goiânia (GO). Revista de Patologia Tropical, 32(2), 45-52.

Teixeira, E., Meinert, E., \& Barbetta, P. (1987). Análise sensorial de alimentos. Florianópolis: Editora da UFSC.

Universidade Estadual de Campinas - UNICAMP. (2011). Tabela Brasileira de Composição de Alimentos (TACO). Versão 3. Campinas: UNICAMP/NEPA. 